\title{
Ergen Bireyselleşme ve Ayrılmasının Tüketici Risk Algısı Üzerine Etkisi
}

\author{
Ezgi KARATAŞ YÜCEL ${ }^{*}$ \\ Engin YÜCEL ${ }^{* *}$
}

\section{$\ddot{O} z$}

Günlük yaşantısında sayısız satın alım yapan tüketiciler, karar verirken pek çok kriteri bazen farkına bile varmadan dikkate almaktadır. Tüketici tarafindan her satın alma davranışı bir risk alma faaliyeti olarak algllanabilmektedir. Ayrıca her tüketicinin risk algısı düzeyi ürün kategorilerine ve bireylerin içinde bulunduklarl yaşam dönemlerine göre farklllık göstermektedir. Tüketicilerin, kişilik oluşumunun önemli ölçüde tamamlandığı ergenlik döneminin de risk algısının farklılaşmasında önemli olduğu düşünülmektedir. Bu kapsamda tüketicilerin ergenlik dönemlerinde ailesi ve çevresiyle olan ilişkilerinin ve ayrlma-bireyselleşmelerinin tüketicilerin risk algllarl üzerindeki etkilerinin incelenmesi bu araştırmanın amacını oluşturmaktadır. Ayrılma bireyselleşme döneminde olan 370 üniversite ögrencisinden anket yöntemiyle elde edilen veriler ışı̆̆ında ergenlik dönemi ayrılmabireyselleşmelerinin tüketicilerin risk alglları üzerindeki etkileri incelenmiştir. Ergenlik dönemi bireyselleşme-ayrılma davranışına ilişkin reddedilme beklentisinin ve ayrılık kaygısının tüketicilerin risk alglları üzerinde anlamlı etkileri olduğu belirlenmiştir. Araştırma bulguları dikkate alınarak literatüre katkısı açısından bazı önerilerde bulunulmuştur.

Anahtar Kelimeler: Tüketici, bireyselleşme-ayrlma, algılanan risk.

Jel Kodlart: M 30, M 31, M 39.

\section{The Effect of Individuation and Separation of Adolescence on Consumer's Perception of Risk}

\begin{abstract}
Consumers who make numerous purchases in everyday life can take into account many criteria when deciding sometimes without even realizing. Each purchasing behaviour can be perceived as a risk taking activity by the consumer. Also, the risk perception level of each consumer differs according to product categories and according to the life periods in which they live. In this context, purpose of the study is examining the effects of relationships of the consumers with their family and surroundings during adolescence and separation-individuation on consumers' risk perceptions. The effects of adolescent separation and individuation on consumer perceptions of risk have been examined in light of the data obtained from 370 university students who are in separation individuation period by survey method. It has been determined that rejection expectancy and separation anxiety, regarding adolescence individuation - separation behaviour, have significant effects on consumers' risk perceptions. Considering the research findings, some suggestions were made in terms of literature contribution.
\end{abstract}

Keywords: consumer, individuation-separation, perceived risk.

Jel Codes: M 30, M 31, M 39.

\footnotetext{
*Araş. Gör. Dr., Dokuz Eylül Üniversitesi, İ.İ.B.F. İşletme Bölümü, ezgi.karatas@deu.edu.tr ORCID: https://orcid.org/0000-0001-5903-3091

** Araş. Gör., Dokuz Eylül Üniversitesi, İ.İ.B.F. İşletme Bölümü, engin.yucel@deu.edu.tr

ORCID: https://orcid.org/0000-0001-8910-5359
} 


\section{Giriş}

Günümüzde bireylerin alışveriş yapmadan bir gün bile geçirmeleri neredeyse imkânsız hale gelmeye başlamıştır. Sabah uyandığı zaman günlük ekmek ihtiyacını satın almak için bir mahalle bakkalına uğramaktan tüm yaşamı boyunca çalışarak hak ettiği emekli tazminatı ile ev satın almaya, çalıştığı ofiste kullanmak üzere kırtasiye malzemeleri satın almaktan elindeki birikim ile lüks otomobil satın almaya kadar pek çok farklı durum ve ürün çeşitliliği arasında alışveriş yapmak kaçınılmaz olmaktadır. Bununla birlikte her ne kadar durum ve ürün satın alım kararının verilmesinde önemli kriterler olsalar da satın alımı gerçekleştirecek karar verici olarak bireylerin özellikleri de göz ardı edilemeyecek bir kriter olarak ortaya çıkmaktadır. Bireylerin özellikleri pek çok koşulla etkileşim halinde olup, yaşam süreci içerisinde her dönemin kendine özgü yeni koşullar ve dolayısıyla tüketicinin özelliklerinde değişimlerle sonuçlandığını söylemek mümkündür.

Yaşam dönemi içerisindeki belirli dönüm noktaları bireylerin kendilerini tanımaları ve kendileri olmaları açısından önem arz etmektedir. Ergenlik dönemi bu dönemlerin en önemlileri arasında sayılabilir. Yenidoğan, bebeklik ve çocukluk dönemlerinin devamında girilen ergenlik dönemi bireylerin çocukluk dönemi ile benzer davranışlar sergilemelerinin yanında yetişkin bir birey gibi davranıp yetişkin hareketleri sergilemeye de başladıkları bir dönem olarak ele alınabilir. Kısacası, ergenlik dönemi bireylerin çocukluk döneminin bitişi ve yetişkinliğe geçişte ara dönem olarak görülmektedir. Yenidoğandan bebekliğe geçişte nasıl ki birey annesinden bağımsız bir birey olduğunu keşfetmeye başlıyorsa ergenlik döneminde de ailesinden bağımsız düşünebilen, ailesinden ayrı yaşamını sürdürebilecek olan, kendi düşünce, inanç, tutum, algı vb. davranışları olan bir birey olduğunun ayırdına varmaktadır. İkinci bireyselleşme ayrılma dönemi de denilebilecek bu dönemde birey adeta kendini çevresine bir birey olarak kabullendirmeye çalışmakta ve dolayısıyla ailesinden ayrılmaya ve bireyselleşmeye başlamaktadır.

Tüketiciler yaptıkları satın alımlarda kendilerine belirli sınırlar çizmektedirler ve satın alım sırasında olası sonuçlar ancak çizdikleri bu sınırlar arasında kalıyor ise satın alım gerçekleştirmektedirler. Bu sınırları belirlemede çok kullanılan kriterlerin biri ürünü satın alırken algıladıkları bir risk olup olmadığıdır. Algıladıkları bir risk varsa bu riskin katlanılabilirlik düzeyi ve ne tür bir risk olduğu satın alım kararı sırasında tüketicinin değerlendirme yapmasında belirleyici olmaktadır. Tüketicilerin algıladıkları fonksiyonel, fiziksel, finansal, sosyal, psikolojik risk ve zaman riskinin düzeyi nihai satın alım yapılıp yapılmayacağı konusunda önemli bir belirleyici unsurdur.

Yapılan bu çalışma, tüketicilerin yaşamlarında duygusal, fiziksel, psikolojik vb. anlamında değişime uğradıkları ergenlik döneminde yaşadıkları ayrılma bireyselleşmenin algıladıkları risk üzerine etkisini incelemektedir. Bu inceleme sırasında öncelikle kuramsal bir altyapı oluşturulması amacıyla risk algısı ve ergen bireyselleşme ayrılması kavramlarına daha sonra ise ergenlik - risk ilişkisine yer verilecek olup son bölümde ise kurulan bu ilişki üzerine yapılan alan araştırmasına yönelik bulgular ortaya koyulacaktır.

\section{Kuramsal Çerçeve}

\subsection{Risk Algısı}

Risk kelimesi pek çok araştırmacı tarafından sayısız defa tanımlanan bir kavramdır. Bununla birlikte Athearn (1971: 639) yapılan pek çok tanımı ele almış bu tanımların ortak noktasının riski belirsizlikle bağdaştırmak olduğunu ve yapılan tanımların geleceğe göndermede bulunduklarını vurgulamıştır. Risk alanında en çok atıf alan çalışmalardan birini yazmış olan 
Kaplan ve Garrick (1981: 12) ise eserlerinde risk kavramının niceliksel özelliklerini ele almış ve risk kavramının 1980 sonrası giderek popülerleşmesi beklenen bir kavram olduğunu ve bu kavramın gerek endüstriyel gerekse kamusal anlamda sıklıkla kullanımının artacağını belirtmektedirler. Kısaca "istenmeyen sonuçlarla karşılaşma olasılığı” olarak tanımlanabilecek olan riskin temelinde herhangi bir karar verme durumunda gelecekteki bir olayla ilgili kesin bilgiye sahip olmama durumu yatmaktadır (Özbilgin, 2012: 88). İşletme bilimi açısından ele alındığında ise "cesaret etmek, üstlenmek, girişim, ekonomik başarı umudu" gibi kavramları açıklamak amacıyla kullanılmaya başlanmıştır (Skjong, 2005).

Algılama ise "insanoğlunun çevresindeki dünyayla bilişsel temas biçimi, bireyin çevresinde olup biteni fark etme şekli”" olarak tanımlanabilir (Efron, 1969: 137). Algı bireylerin ne gördügünü, nasıl yorumladığını, neye inandığını, nasıl davrandığııı ortaya koyması açısından oldukça önemli bir davranışsal kavramdır (Bakan \& Kefe, 2012: 21). En basit anlamda duyu organları tarafindan toplanan verilerin bir araya gelip yorumlanması ile elde edilen yargı olarak ele alınabilecek olan algı sayesinde bireyler çevresinde gerçekleşen her türlü olayı anlamlandırmaya çalışmaktadır.

Tüketicilerin satın alma kararının sonuçları ile ilgili belirsizliklere sahip olması ise pazarlama açısından risk algısı kavramını yaratmaktadır. Risk algısı ya da diğer bir ifade ile algılanan risk kavramının pazarlama yazınında yer almasını sağlayan ilk çalışma 1960 yılında Raymond A. Bauer tarafından yapılmıştır. Her ne kadar Bauer çalışmasında en azından birkaç araştırmacının dikkatini çekmesi açısından kavramı ortaya sürdügünü belirtse de algılanan risk kavramı 1960 yılından günümüze dek uluslararası karşılaştırmalar, perakendecilik, tüketici davranışları gibi pek çok alanda sayısız çalışmaya konu olmuştur (Mitchell, 1999: 163). Bauer'in görüsslerine göre her tür tüketici satın alma davranışı birer risk alma faaliyeti olarak düşünülmelidir. Çünkü tüketiciler belirsizliği ortadan kaldırmak için her yolu deniyor olsalar da yine de davranışlarının sonunda tatmin olmama ihtimalleri bulunmaktadır (Bauer, 1974). Her ne kadar algılanan risk tüketicinin özellikleri, ürünün özellikleri, satıcının özellikleri, pazarın yapısı gibi satın alma davranışını etkileyen pek çok faktöre göre ve de düzey olarak değişkenlik gösterse tüketicilerin her satın alımının bir risk taşıdığını söylemek mümkündür (Taylor, 1974: 54-55). İnsanların yaşamları boyunca varoluşlarını sürdürmek için zorunlu olarak yaptıkları tüketim davranışlarını doğru bir şekilde anlamak için her tür tüketici davranışında ortaya çıkmakta olan algılanan risk kavramının doğru anlaşılmasının ise pazarlama alanına katkı sağlayacağı düşünülmektedir.

Tüketicinin bir ürün satın alırken risk algılamasının altında pek çok neden yer alabilmektedir. Mitchell (1999: 172)'e göre risk algısının kökeninin anlaşılması için öncelikle risk algılamasının kaynaklarının neler olduğunu tanımlamak gerekmektedir ve sayısız risk kaynağından söz etmek mümkündür. Riskin kaynağı tüketicinin kendi ihtiyaçlarını, satın alma hedeflerini ve bu hedeflerin önemini bilmemesi olabileceği gibi, karar alternatiflerini tam belirlememek, yapılan ürün değerlendirmelerinin geçerli olup olmadığını bilmemek, riskin sonuçlarının doğru bir şekilde anlaşılmamış olması da olabilir.

Tüketicilerin algıladıkları riskin kaynağı değişim gösterdikçe riski algılamasında da çeşitli farklılıklar ortaya çıkması kaçınılmazdır. Lim (2002: 542)'e göre bu farklılıkların anlaşılması, gerek işletmelerin tüketicilerin kendi işletmelerinde algıladıkları riskleri düşürerek tüketicilerin kendilerini güvende hissettikleri satın alımlar yapmaları açısından gerekse tüketicinin kendisini doğru tanıması ve bir satın alım sırasında nasıl riskler üstlendiğini ortaya koyması bakımından oldukça önemlidir. Tüketicilerin algıladıkları riskleri ayrıştırma üzerine ilk çalışmalar 1970'li yıllarda yapılmış olup (Jacoby ve Kaplan, 1972; Roselius, 1971) o tarihlerden günümüze kadar bu alanda çok fazla çalışma ve tanım yapılmıştır. Yapılan literatür 
taramasına göre genel olarak altı algılanan risk türü bulunmaktadır (Tek ve Demirci Orel, 2008: 193; Dal ve Eroğlu, 2015: 367-368; Cheng, Liu, ve Wu, 2013; Demir, 2011). Bu risk türleri satın alınan ürünün iyi bir performans gösterip göstermediği sorusunu ortaya çıkaran fonksiyonel risk, bir ürünün tüketiciye verebileceği zararlardan oluşan fiziksel risk, tüketicinin ürünü satın almaya yetecek bütçeye sahip olup olmamasından doğan finansal risk, ürünün tüketicinin sosyal çevresinde beğenilmeme olasılığını yansıtan sosyal risk, tüketicinin ürünü satın aldıklarında rahatlık hissetmelerini ortaya koyan psikolojik risk ve tüketicilerin ürünü satın alırken harcadıkları zamanla bütünleşen zaman riski olarak gruplandırılabilmektedir.

\subsection{Ergen Bireyselleşme ve Ayrılması}

İnsanlar, doğdukları andan hayatlarını kaybedene kadar bebeklik, çocukluk, ergenlik, yetişkinlik, yaşlılık gibi her biri kendine özgü özelliklere sahip olan belirli dönemlerden geçmektedirler. $\mathrm{Bu}$ özelliklerin yanı sıra her birey farklı fizyolojik, toplumsal, duygusal, etkileşimlerden geçtiği için bu dönemlerin başlangıç ve bitiş tarihlerini net bir ayrıma tabi tutmak pek mümkün olmamaktadır (Koç, 2004: 232-233). Bu yaşam döngüsü içerisinde ergenlik dönemi artık çocukluk dönemini geçirmekte olan ancak tam olarak yetişkin sayılamayacak bireyleri tanımlamakta kullanılmaktadır (Brereton, 2001) ve bireyin yoğun olarak fiziksel, zihinsel ve sosyal - duygusal değişimler yaşaması ve sonunda kendini tanımasını beraberinde getirmesi nedeniyle oldukça önemli olan ve irdelenmesi gereken bir dönemdir (Sayıl, Güre (Y1lmaz), ve Uçanok, 2002: 48).

Gül ve Güneş (2009: 82)'e göre her ne kadar net bir yaş aralığından söz etmek mümkün olmasa da bireyin ve ailesinin yaşam tarzı, genetik faktörler, bedensel gelişim gibi pek çok faktörden etkilenen bu dönemin 9-11 yaşlarında başladığını ve 17-18 yaşına kadar devam ettiğini belirtmek mümkündür. Bu dönemi sağlıklı bir şekilde geçiren bireyler ise ergenlik dönemi sonunda kendini tanıyarak bireyselleşmiş ve ebeveynlerinden ayrılıp bağımsızlığını kazanarak ayrışmış birer yetişkine dönüşmektedir (Haran, 2004: 47-48). Ergenlik dönemine kadar ebeveynlerine bağımlı bir yaşam sürdüren ergen birey, bu dönemde kendi kararlarını alabilme potansiyelini artırmakta ve duygu ve davranışlarında ebeveynlerin aynası olmaktan çıkıp kendi duygu ve düşüncelerini yansıtmaya başlamakta (Özdemir ve Çok, 2011: 154) böylece ayrışmış ve bireyselleşmiş olmaktadır.

Bireylerin ailelerinden ayrı hareket etmesi ve kararlar vermesine dönük olarak yapılan çalışmalar ilk olarak yenidoğanlar üzerinden ele alınmakta ve 1970'li yıllardan itibaren literatürde daha sık yer bulmaktadır. Ancak daha önce pek çok çalışmada çeşitli yönlerden ele alınan bu olgu gelişim psikolojisinde Mahler'in 1975 yılında ortaya attığı gelişim modeli ile yer bulmuştur. Mahler'e göre "birincil ayrılma ve bireyselleşme krizi” olarak adlandırılan 4 36 aylık dönemde birey kendi isteklerinin ilk defa farkına varmakta, annesinden bağımsız da var olduğunu fark etmekte ve bir ayrılmaya ve bireysel davranmaya yönelmektedir (Atak, 2011: 176). Mahler, insanın biyolojik doğumunun gözlemlenebilir, etkileyici ve sınırları belli bir olay iken psikolojik doğumunun ise yavaş yavaş gerçekleșen bir olgu olduğunu belirtmektedir (Mahler vd., 1975). İnsanın biyolojik doğumu ile psikolojik doğumunun aynı anda olmadığını ileri süren bu yaklaşıma göre (Taşkın vd., 2009: 175) bu dönem sonunda birey bağımlı bir bebekten bir çocuğa dönüşmekte ve ilk bireyselliğini kazanmaktadır (Atak, 2011: 177).

Birey bu ilk krizi atlattıktan sonra ise çocukluk dönemine geçmekte ve psikolojik gelişimde ilerlemektedir. "İkinci bireyselleşme krizi”ni ilk ele alan ve bu alanda temel oluşturan isim ise yine 1970'li yıllarda çalışmaları ile ön plana çıkan Peter Blos olmuştur. Blos'a göre bu dönemde sevgi ve nefret nesnelerini birey aile dışında bulmaya yönelmeli, kendi dünyasını 
yaratmaya çalışmalıdır (Yüncü vd., 2009: 226). Bu dönemde kendi içinde ruhsal çatışmalar geçiren ergen dönemin bitişinde bu çalkantılarla şekillenen bir yetişkin birey haline dönüşmektedir. $\mathrm{Bu}$ dönemde bireyler yaşadıkları fiziksel değişimlerin yanında kendini ifade etme ve konuşma dilini kullanma konusunda gelişim gösterme, yalnızca şimdiki zamana odaklanma, kural ve sınırları sınama, ailenin mükemmel olmadığını düşünme, her şeyi yalnız başına yapma, her şeye yalnız başına karar vermeye yönelme, davranış, inanç ve düşüncelerde tutarsızlık gibi pek çok bilişsel değişimler de yaşamaktadır (Brereton, Adolescence and Autism Spectrum).

Ergenlik dönemini ikinci bireyselleşme dönemi olarak ele alan çalışmaların bir kısmı temel olarak Mahler'in görüşünü savunmakta ve ikincil kriz dönemindeki davranışları birincil kriz dönemi ile bütünselleştirmektedir. Ergenlik ve yenidoğan davranışlarını benzeştirerek Mahler'in yenidoğan bireyleşme ayrılma konusundaki psikoanalitik teorisini temel alan Levine vd. (1986) ergenlik döneminin ayrılma ve bireyselleşme ile ilgili endişelerin yeniden ortaya çıktığ 1 bir dönem olduğunu öne sürmektedir (Mattanah vd., 2004: 216). Bu düşünceleri doğrultusunda yaptığ 1 çalışmalar kapsamında ise bireyselleşme - ayrılma ölçümlemede literatürde en sık kullanılan ölçüm aracı olarak 1986 yılında Ergen Ayrılma Bireyselleşme Testi (The Seperation Individuation Test of Adolescence - SITA)'ni geliştirmiştir. Ölçek Levine ve Saintonge (1993) tarafından gözden geçirilmiş ve düzenlenmiş olup ölçekte yer alan 86 madde 5'li Likert tipi ölçekle ölçümlenmiş ve ölçeğin nihai hali 9 alt boyutlu bir yapıyı ortaya koymuştur. $\mathrm{Bu}$ dokuz alt boyut ayrılık kaygısı (separation anxiety), kısıtlanma kaygısı (engulfment anxiety), bakım veren kişiye bağlanma (nurturance seeking), akrana bağlanma (peer enmeshment), öğretmene bağlanma (teacher enmeshment), aynalamayı yaşama (practicing-mirroring), bağl1lı̆̆ inkâr (need denial), reddedilme beklentisi (rejection expectancy) ve sağlıklı ayrılma (healthy separation) olarak sıralanabilir (Aslan ve Güven, 2009: 124).

\subsection{Ergenlik-Risk İlişkisi}

Tüketicilerin risk algısı kişiye, duruma ve ürüne göre farklılık göstermektedir (Dal ve Eroğlu, 2015: 369). Bununla birlikte kendi bütçelerine sahip olmadıkları için yetişkinler kadar satın alım yapmıyor olsalar da gerek doğrudan kendi harcamaları gerekse ailelerinin kendilerine yaptıkları harcamalar açısından ele alındığında gençlerin birer tüketici olarak çok önemli bir pazar oluşturmaya başladıkları ortadadır. Örneğin Amerika'da gençlere yönelik yapılan toplam harcama miktarı 264,038,000,000 \$ iken yine aynı şekilde gençlerin yıllık gelirleri $92,450,000,000$ \$'dır (Statistic Brain, 2017). Türkiye'de harcamalara ilişkin net bir rakam bulunamamış olsa da 2016 yılı sonunda 10-19 yaş aralığında yer alan nüfusun 9.846.195 kişi olduğu göz önünde bulundurulduğunda bu sayının tüketim açısından göz ardı edilemez olduğu söylenebilir (Türkiye İstatistik Kurumu, 2016).

Net bir yaş ayrımı yapılmıyor olsa bile genç nüfusun içinde bulunduğu varsayılabilecek olan ergenlik döneminde tüm diğer davranışlarda olduğu gibi ergenler bireyselleşme çabası göstermekte ve harcamalarını kişiselleştirmeye birer tüketici olarak bağımsız hareket etmeye ve yaptıkları satın alma tercihleri ile kimliklerini yansıtmaya çalışmaktadırlar. Ergenler ortalama olarak harcamalarının \%23'ünü yiyeceklere, \%20'sini giyime, \%10'unu aksesuarlara, $\% 8$ 'ini video oyunlarına, \%8'ini arabalara, \%8'ini elektroniğe, \%7'sini ayakkabıya kalanını ise müzik, film ve etkinliklere harcayan bu grup harcamalarında genellikle belirli markalar tercih etmekte (Business Insider, 2015) ve seçtikleri markalarla sosyal grupları açısından da özdeşleşmektedirler. 
Özdemir ve Çok (2011: 153)'a göre ergenlik döneminde yoğunlaşan bağımsızlık çabaları beraberinde risk alma davranışlarında da artış ile sonuçlanmaktadır. Stresle başa çıkmak, sıkılmayı önlemek, duygu arayışında olmak, sonucunu merak etmek gibi nedenler ile ergenler risk almaya yönelebilmektedir (Jessor, 1999: 9). Bu tartışmalar ışığında ergenlik döneminde yaşanan ayrılma bireyselleşme davranışlarının tüketim davranışları üzerinde etkisi olduğu düşünülmektedir.

\section{Metodoloji}

\subsection{Araştırmanın Amacı}

Tüketicilerin risk algıları farklı olmakla birlikte bu algıların zaman içerisinde değişiklik gösterdiği de bilinmektedir. Çocukluk ve ergenlik dönemlerinde yaşanan ayrılma ve bireyselleşme risk algısının oluşumunda ve algılanan risk türlerinin farklılaşmasında önemli bir süreç haline gelmektedir. Tüketicilerin farklı ürün kategorilerinde risk algıları farklılık göstermekle beraber genel olarak tüketicilerin ergenlik dönemlerinde ailesi ve çevresiyle olan ilişkilerinin ve ayrılma bireyselleşmelerinin tüketicilerin risk algıları üzerindeki etkilerinin incelenmesi bu araştırmanın amacını oluşturmaktadır.

\subsection{Araştırmanın Modeli ve Hipotezleri}

Araştırmanın ana amacı ergenlik dönemi ayrılma bireyselleşme sürecinin tüketicilerin risk algıları üzerindeki etkilerini değerlendirmektir. Ancak araştırma kapsamında tüketicilerin risk algılarının cinsiyet ve gelir düzeyi gibi demografik değişkenler açısından farklılıkları da ölçülmüştür.

Araştırmanın amacına uygun olarak ergenlik dönemi ayrılma bireyselleşme sürecinin tüketicilerin risk algıları üzerindeki etkilerinin ele alındığı model Şekil 1' de gösterilmektedir.

Şekil 1: Araştırmanın Modeli

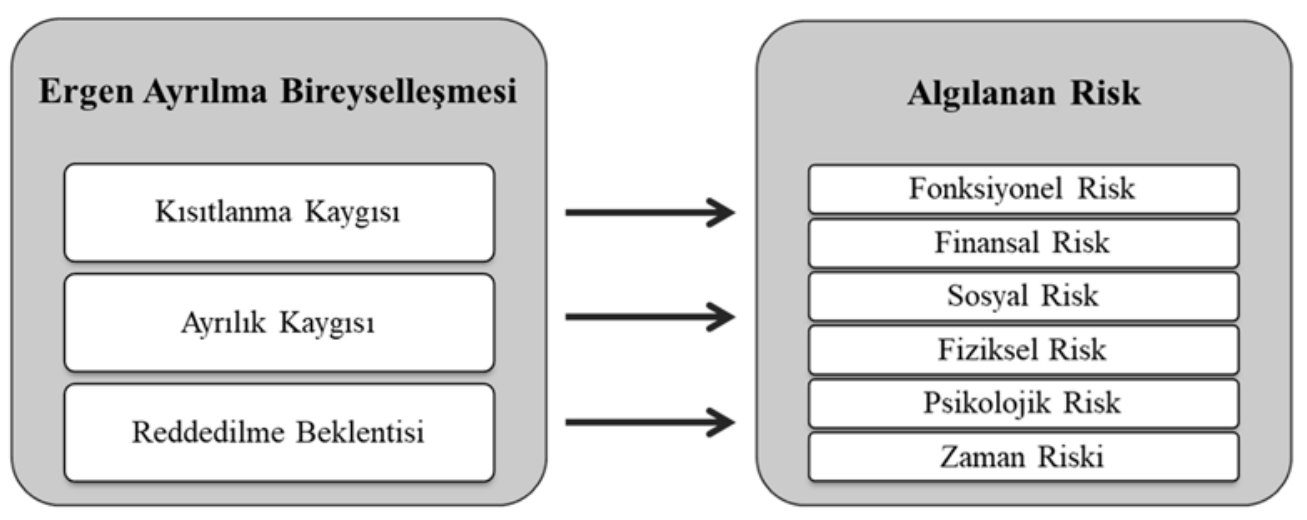

Ergen ayrışma bireyselleşme sürecinin katılımcıların risk algıları üzerindeki etkilerini ölçmeye yönelik olarak tasarlanmış olan bu model kapsamında oluşturulan hipotezler şu şekildedir:

$\mathrm{H}_{1}$ : (a) Kısıtlanma kayg1sı, (b) Ayrilık kaygıs1 ve (c) Reddedilme beklentisi fonksiyonel riski etkilemektedir.

$\mathrm{H}_{2}$ : (a) Kısıtlanma kaygısı, (b) Ayrılık kaygısı ve (c) Reddedilme beklentisi finansal riski etkilemektedir. 
$\mathrm{H}_{3}$ : (a) Kistlanma kaygıs1, (b) Ayrılık kaygisı ve (c) Reddedilme beklentisi sosyal riski etkilemektedir.

H4: (a) Kısıtlanma kaygısı, (b) Ayrılık kaygısı ve (c) Reddedilme beklentisi fiziksel riski etkilemektedir.

H5: (a) Kısıtlanma kaygısı, (b) Ayrilık kaygisı ve (c) Reddedilme beklentisi psikolojik riski etkilemektedir.

H6: (a) Kısıtlanma kaygısı, (b) Ayrılık kaygısı ve (c) Reddedilme beklentisi zaman riskini etkilemektedir.

\subsection{Araștırmanın Yöntemi}

Yapılan bu çalışmada araştırmanın amaçlarına ulaşmaya yönelik soru formunu oluşturmada iki ölçek temel alınmıştır. Bu ölçekleri ilişkin ayrıntılı bilgi aşağıda yer almaktadır.

a. Ergen Ayrlma - Bireyselleşme Ölçeği: Literatür taraması bölümünde değinildiği üzere ölçek esas hali itibari ile 9 alt boyuttan ve 86 ifadeden oluşsa da bu alanda yapılan çalışmaların amaçları doğrultusunda yalnızca ilgili boyutlar ele alınmaktadır. Mattanah vd. (2004: 216)'ya göre öğrencilerin ayrılma süreci ile ilgili endişelerini ortaya koyan ve öğrencilerin uyumlu davranışlar göstermesi ve aile bireyleri ile olan bağlantılarını ayrılık kaygısı, kısıtlanma kaygısı ve reddedilme kaygısı olarak üç boyut ortaya koymaktadır. Bununla birlikte ergen ayrılma bireyselleşme ölçeğinin geçerlilik güvenirlik çalışmaları Aslan ve Güven (2009) tarafından yapılmış olup bu çalışmada ayrılık kaygısı, kısıtlanma kaygısı ve reddedilme kaygısı olarak üç boyut geçerli ve güvenilir olarak Türkçe 'ye uyarlanmıştır. İlgili çalışma ve bu çalışmanın ortaya koyulduğu Aslan (2008)'a ait doktora tezi yapılan bu çalı̧̧ada Ergenlik Bireyselleşme ve Ayrılması'nın ölçülmesinde temel oluşturmuştur. Söz konusu üç boyutlu yapıyı ölçmede ilgili 31 ifade 5'li Likert tipi ölçekle 1- Kesinlikle Katılmıyorum, 2Katılmıorum, 3- Ne Katıllyorum Ne Katılmıyorum, 4- Katıliyorum ve 5- Kesinlikle Katılıyorum olacak şekilde ölçümleme yapılmıştır.

b. Algılanan Risk Ölçeği: Literatür taraması sırasında tanımlanmış olan altı risk grubunu (fonksiyonel risk, finansal risk, sosyal risk, fiziksel risk, psikolojik risk ve zaman riski) ölçümlemek üzere Stone ve Mason'un 1995 yılında geliştirmiş oldukları ve pek çok çalışmanın yürütülmesinde ölçüm aracı olarak kullanılmış olan ölçek temel alınmıştır. Bu ölçek toplamda 18 maddeden oluşmakta ve her bir alt boyutu 3 soru ile ölçümlemektedir (Stone ve Mason, 1995). Ergen Ayrılma - Bireyselleşme Ölçeği ile benzer şekilde risk algısını ölçümlemede de 1- Kesinlikle Katılmıyorum, 2- Katılmıyorum, 3- Ne Katılıyorum Ne Katılmıyorum, 4Katılıyorum ve 5- Kesinlikle Katıllyorum olacak şekilde Likert tipi ölçek kullanılmıştır.

\subsection{Araştırmanın Evreni ve Örneklem Yapısı}

Araştırma kapsamında birincil veri elde etmek amacıyla veri toplama yöntemi olarak anket tekniği kullanılmıştır. Alan araştırması gerçekleş̧irilmeden önce soruların katılımcılar açısından anlaşılırlığının test edilmesi amacıyla kolayda örnekleme yöntemiyle 75 kişilik bir gruba ön test yapılmıştır. Araştırmanın örneklemini 2016-2017 öğretim yılında bahar döneminde Dokuz Eylül Üniversitesi İktisadi ve İdari Bilimler Fakültesi’nde öğrenim gören ve 17-31 yaş aralığında yer alan 193 kadın ve 177 erkek olmak üzere 370 öğrenci oluşturmaktadır.

Araştırmada üniversite öğrencilerinin örneklem olarak seçilmesinde temel neden ikinci ayrılma bireyselleşme dönemi olan ergenlik döneminde gelişimin en belirginleştiği, bireylerin 
ailelerinden uzakta ve bağımsız karar aldıkları ve dolayısıyla aileden kopma yaşadıkları dönemin üniversite eğitimi aldıkları dönem olmasıdır (Mattanah vd., 2004: 213). 43 anket hatalı, eksik veya gelişigüzel doldurulması sebebiyle değerlendirme dışı bırakılmıştır. Dolayısıyla nihai haliyle analizler 327 anketten elde edilen verilerle yürütülmüştür. Örneklemin sosyodemografik profili Tablo 1'de görülmektedir.

Tablo 1: Örneklemin Sosyo-Demografik Profili

\begin{tabular}{|l|c|c|l|c|c|}
\hline Cinsiyet & Fre. & $\%$ & Yaş & Fre. & $\%$ \\
\hline Kadın & 193 & 52,1 & $18-21$ & 165 & 44,6 \\
\hline Erkek & 177 & 47,9 & $22-25$ & 178 & 48,1 \\
\hline Kişi başı aylık gelir & & & 26 ve üzeri & 27 & 7,3 \\
\hline $0-300$ & 44 & 11,9 & Kardeş Sayısı & & \\
\hline $301-600$ & 88 & 23,8 & $1-2$ & 198 & 53,5 \\
\hline $601-900$ & 86 & 23,3 & $3-4$ & 134 & 36,2 \\
\hline $901-1200$ & 66 & 17,8 & $5-6$ & 26 & 7,1 \\
\hline 1201 ve üzeri & 86 & 23,2 & 7 ve üzeri & 12 & 3,2 \\
\hline
\end{tabular}

\section{5. Ölçeklere İlişkin Geçerlilik ve Güvenilirlik Analizleri}

Araştırma kapsamında öncelikli olarak Ergen Ayrılma Bireyselleşme Testi ölçeğinin ve Algılanan Risk ölçeğinin geçerlilik ve güvenilirlik analizlerine yer verilmiştir. Bu sayede her iki ölçeğin de iç geçerliliği ve kapsam geçerliliğini sağlayıp sağlamadığ 1 test edilmiştir. Ölçeklerin yapı geçerliliğini test etmek amacıyla açıklayıcı faktör analizi uygulanmıştır (Lu, 2006: 81). İfadelere ilişkin \%40 ve üzeri faktör yükleri kabul edilmiştir (Stevens, 1992: 384). Veri setinin faktör analizine uygunluğunu gösteren KMO değerinin \%60'ın üzerinde olması dikkate alınmıştır (Kaiser, 1974: 35). Güvenilirlik analizi ölçütü olan Cronbach Alpha değerinin ise \%70 ve üzeri düzeylerde olması anlamlı kabul edilmektedir (Nunnally ve Bernstein, 1994: 264-265). Her iki ölçeğe ait geçerlilik ve güvenirlilik analizleri ayrı ayrı ele alınmıştır.

a. Ergen Ayrılma Bireyselleşme Testi Ölçeği: Araştırma kapsamında kullanılan Ergen Ayrılma Bireyselleşme Testi ölçeğine ait 31 ifadenin normallik şartlarını sağlayıp sağlamadığı değerlendirilmiştir. Bu kapsamda ifadelerin Kurtosis ve Skewness değerleri incelenmiş olup "Ailemin benden istedikleri, sık sık bana isyan duygusu yaşatır (Kısıtlanma7)" ve "Yaşadığım sıkıntıları birine anlatsam, muhtemelen anlamayacaktır (Reddedilme2)" ifadeleri normallik şartlarını sağlamadığı için soru setinden çıkarılmıştır (Limpert ve Stahel, 2011: 5). Faktör analizi sonucu Tablo 2'de görülmektedir.

Faktör analizi sonuçlarına göre Reddedilme1, Reddedilme7, Reddedilme9, Reddedilme11, Ayrılık4, Ayrılık5 ve Ayrılık7 maddeleri düşük ve çapraz faktör yükleri nedeniyle veri setinden çıkarılmıştır. Verilerin açıklayıcı faktör analizine uygunluğunu değerlendiren Kaiser - Meyer - Olkin (KMO) değerinin "KMO $\geq 0.60$ " koşulunu sağladığ görülmektedir. 31 ifadeden oluşan Ergen Ayrılma Bireyselleşme Testi Ölçeği normallik analizi sonucunda 29 ifadeye, faktör analizi sonucunda ise 22 ifadeden oluşan 3 faktörlü bir yapıya dönüşmüştür. Reddedilme Beklentisi, Ayrılık Kaygısı ve Kısıtlanma Kaygısı olarak ortaya çıkan üç faktörlü yapının açıklanan varyansı ise 43,843'tür. Faktörlerin güvenilirlik düzeyleri ise $\% 73$ ile $\% 81$ arasında değişmektedir. 
b. Algılanan Risk Ölçeği: Algılanan Risk ölçeğine ait 18 maddeden "Yeni bir ürünün aldığım paraya değmesini isterim (Finansal3)" ifadesi, normallik şartlarını sağlamadığ gerekçesiyle veri setinden çıkarılmıştır. Diğer ifadelere ilişkin uygulanan Faktör analizi sonuçları Tablo 3'de görülmektedir.

Tablo 2: Ergen Ayrılma Bireyselleşme Testi Ölçeği Açıklayıcı Faktör Analizi

\begin{tabular}{|c|c|c|c|}
\hline \multicolumn{4}{|c|}{ Ergen Ayrılma Bireyselleşme Testi } \\
\hline & $\begin{array}{c}\text { Reddedilme } \\
\text { Beklentisi }\end{array}$ & $\begin{array}{l}\text { Ayrılık } \\
\text { Kaygis1 }\end{array}$ & $\begin{array}{c}\text { Kisitlanma } \\
\text { Kaygis1 }\end{array}$ \\
\hline Reddedilme6 & 0,802 & & \\
\hline Reddedilme10 & 0,762 & & \\
\hline Reddeilme5 & 0,719 & & \\
\hline Reddedilme12 & 0,693 & & \\
\hline Reddedilme3 & 0,663 & & \\
\hline Reddedilme4 & 0,511 & & \\
\hline Reddedilme8 & 0,489 & & \\
\hline Ayrilık11 & & 0,659 & \\
\hline Ayr1l1k12 & & 0,593 & \\
\hline Ayr1l1k6 & & 0,586 & \\
\hline Ayrılık10 & & 0,577 & \\
\hline Ayr1lik9 & & 0,551 & \\
\hline Ayrılık1 & & 0,532 & \\
\hline Ayr1l1k3 & & 0,503 & \\
\hline Ayr1lık2 & & 0,496 & \\
\hline Ayr1lik8 & & 0,471 & \\
\hline Kisitlanma1 & & & 0,743 \\
\hline Kisitlanma4 & & & 0,73 \\
\hline Kisitlanma5 & & & 0,673 \\
\hline Kisitlanma2 & & & 0,609 \\
\hline Kisitlanma3 & & & 0,563 \\
\hline Kisitlanma6 & & & 0,497 \\
\hline Açıklanan Varyans & 17,951 & 14,137 & 11,755 \\
\hline Güvenilirlik & 0,810 & 0,733 & 0,740 \\
\hline \multicolumn{4}{|c|}{$\mathrm{KMO}=0,784 ;$ Barlett $=2199,377 ; \mathrm{p}=0,000$} \\
\hline
\end{tabular}

Psikolojik3 maddesi çapraz ve düşük faktör yükü sebebiyle veri setinden çıkarılmıştır. 16 ifadeden oluşan 5 faktörlü bir yapı ortaya çıkmıştır. Fonksiyonel risk ve finansal risk boyutuna ait ifadeler ortak bir faktörde yer almıştır. KMO ve Barlett değerlerinin faktör analizi için yeterli düzeyde olduğu görülmektedir. Fonksiyonel Risk, Sosyal Risk, Zaman Riski, Psikolojik Risk ve Fiziksel Risk olarak ortaya çıkan beş faktörlü yapının toplam açıklanan varyansı ise 61,243’tür. Faktörlerin güvenilirlik düzeyleri ise \%72 ile \%82 arasında değişmektedir. 
Tablo 3: Algılanan Risk Ölçeği Açıklayıcı Faktör Analizi

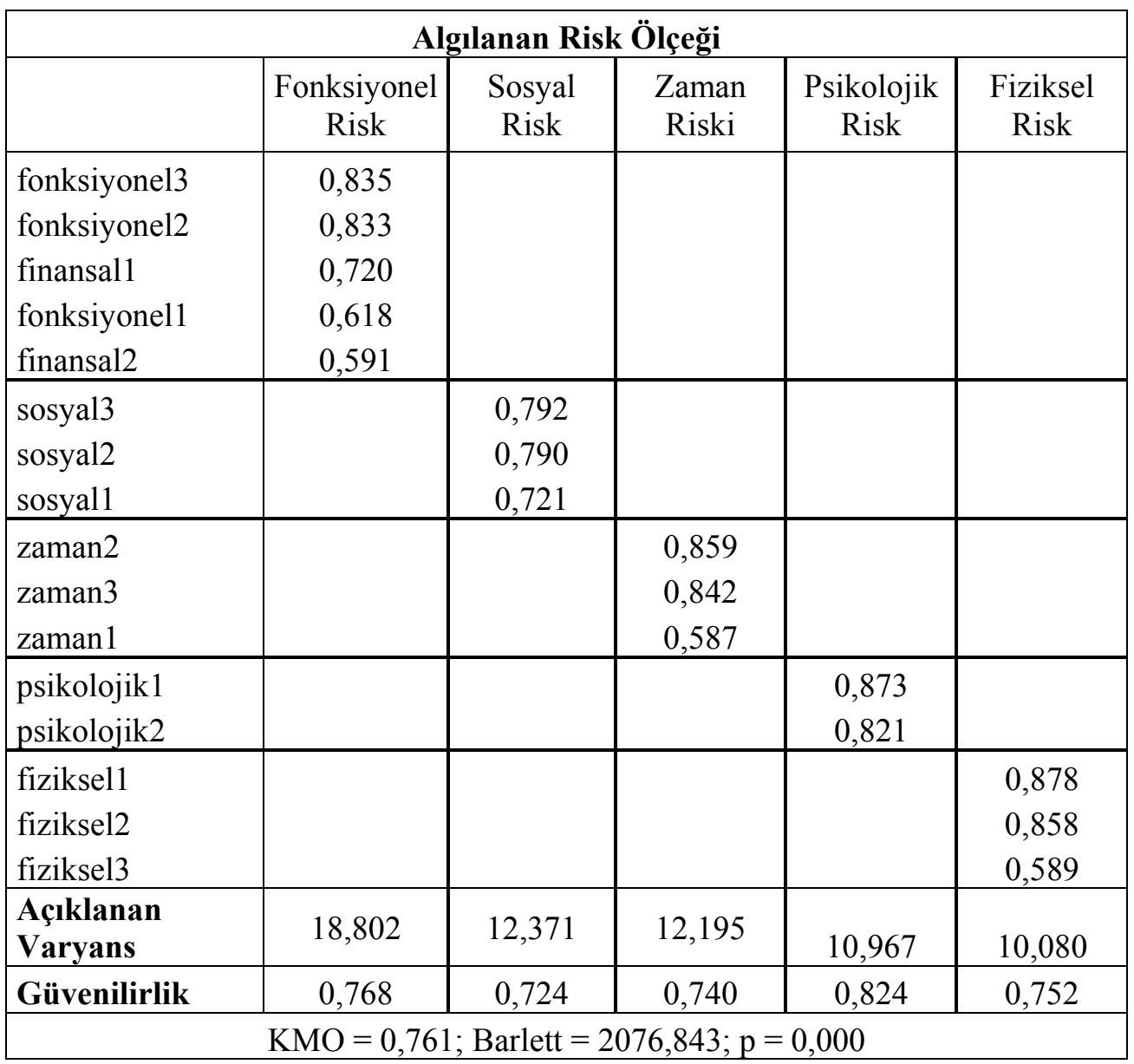

\subsection{Ergenlik Dönemi Bireyselleşme ve Ayrılmanın Risk Algısına Etkisi}

Ergenlik dönemi bireyselleşme ve ayrılmanın kişilerin risk algıları üzerindeki etkilerini incelenmesi amacı doğrultusunda kullanılan regresyon analizi, bağımlı bir değişkenin bağımsız değişkenler tarafından nasıl açıklandığını belirlemek için kullanılmaktadır (Sipahi vd. 2011: 154). Ergenlik dönemi bireyselleşme ve ayrılmaya ilişkin reddedilme beklentisi, ayrılık kaygısı ve kısıtlanma kaygısı bağımsız değişkenleri oluştururken; risk algısı boyutları fonksiyonel, sosyal, zaman, psikolojik ve fiziksel risk bağımlı değişkenler olarak ele alınmıştır. Regresyon analizlerine ilişkin istatistikler Tablo 4'de gösterilmiştir.

Elde edilen beş farklı modelin de anlamlı olduğu görülmektedir. Analiz sonuçlarına göre Ergenlik Dönemi Bireyselleşme ve Ayrılma testinin alt boyutu olan ayrılık kaygısı; algılanan riskin alt boyutları fonksiyonel riski, fiziksel riski ve zaman riskini pozitif yönde etkilemektedir. Ayrıca reddedilme beklentisi, sosyal riski ve zaman riskini pozitif yönde etkilerken; fonksiyonel riske ve fiziksel riske etkisi negatiftir. Bu kapsamda $\mathrm{H}_{1 b}, \mathrm{H}_{1 c}, \mathrm{H}_{3 b}, \mathrm{H}_{3 c}, \mathrm{H}_{4 b}, \mathrm{H}_{4 c}$, $\mathrm{H}_{5 \mathrm{c}}, \mathrm{H}_{6 \mathrm{~b}}$ ve $\mathrm{H}_{6 \mathrm{c}}$ hipotezleri desteklenmiştir. 
Tablo 4: Ergenlik Dönemi Bireyselleşme ve Ayrılma - Risk Algısı Regresyon Analizi Sonuçları

\begin{tabular}{|c|c|c|c|c|c|c|}
\hline & Bağımsız Değiş̧kenler & B & $\mathbf{t}$ & $\mathbf{F}$ & $\mathbf{R}^{2}$ & $\mathbf{p}$ \\
\hline \multirow{3}{*}{$\begin{array}{c}\text { Fonksiyonel } \\
\text { Risk }\end{array}$} & Sabit & 3,336 & 16,411 & \multirow{3}{*}{7,937} & \multirow{3}{*}{0,068} & 0,000 \\
\hline & Ayrilık Kaygisı & 0,237 & 4,237 & & & 0,000 \\
\hline & Reddedilme Beklentisi & $-0,142$ & $-2,696$ & & & 0,007 \\
\hline \multirow{2}{*}{ Sosyal Risk } & Ayrilık Kaygisı & 0,398 & 5,828 & \multirow{2}{*}{26,307} & \multirow{2}{*}{0,196} & 0,000 \\
\hline & Reddedilme Beklentisi & 0,335 & 5,170 & & & 0,000 \\
\hline \multirow{3}{*}{ Fiziksel Risk } & Sabit & 3,562 & 14,953 & \multirow{3}{*}{10,969} & \multirow{3}{*}{0,091} & 0,000 \\
\hline & Ayrilık Kaygis1 & 0,261 & 4,081 & & & 0,000 \\
\hline & Reddedilme Beklentisi & $-0,249$ & $-4,083$ & & & 0,000 \\
\hline \multirow{2}{*}{$\begin{array}{c}\text { Psikolojik } \\
\text { Risk }\end{array}$} & Sabit & 0,913 & 3,725 & \multirow{2}{*}{14,406} & \multirow{2}{*}{0,116} & 0,000 \\
\hline & Reddedilme Beklentisi & 0,377 & 5,977 & & & 0,000 \\
\hline \multirow{3}{*}{ Zaman Riski } & Sabit & 1,187 & 4,264 & \multirow{3}{*}{12,375} & \multirow{3}{*}{0,101} & 0,000 \\
\hline & Ayrilık Kaygisı & 0,174 & 2,314 & & & 0,021 \\
\hline & Reddedilme Beklentisi & 0,330 & 4,630 & & & 0,000 \\
\hline
\end{tabular}

\section{Sonuç}

Bireyin davranışlarının aile, yaşam tarzı, gelir gibi pek çok değişkenden etkilendiği bilinmektedir. Bununla birlikte bireylerin yaşamları boyunca belirli evrelerden geçtikleri ve bu evrelerin her birinde birer birey dolayısıyla da birer tüketici olarak farklılaştıklarını söylemek mümkündür. Yenidoğan olarak hayata atılan bireylerin dönüşüm yaşadıkları ilk nokta annelerinden bağımsız olduklarını keşfettikleri ve kendi kararlarını verebileceklerini kendi hareketlerini kontrol edebileceklerini fark ettikleri bebekliğe geçiş aşamasıdır. $\mathrm{Bu}$ aşamada birey annesinden ayrılmakta ve kendini kontrol edebildiği için bireyselleşmeye başlamaktadır.

Bebekliğe geçiş aşamasına benzer şekilde çocukluk döneminden yetişkinliğe geçişte de bireyler ailelerinden ayrı iken de hayatta kalabildiklerini, kendi kararlarını bağımsız olarak verebileceklerini fark etmekte ve yine bu dönem kendi düşüncelerini ön planda tutmakta ailelerinden kopmaya çalışmaktadırlar. İkinci ayrılma bireyselleşme dönemi olarak adlandırılan bu dönem çocukluktan yetişkinliğe geçiş şaması olduğu için bireylerin yaşamında önemli bir adım olarak karşılarına çıkmaktadır.

Tüketicilerin davranışları ürün, marka, durum gibi dışsal değişkenlerle birlikte bireyin kendine has özelliklerine göre de değişim göstermektedir. Bireyler satın alma kararını ancak satın alım yapmayı düşündükleri ürünler ve hizmetler kendilerine göre satın alım yapmaya değecek ise vermektedirler. Bir ürünün satın alınmasının değerli olup olmaması noktasında ise söz konusu ürünün veya hizmetin tüketici açısından yarattığı riskler ön plana çıkmaktadır. Bir satın alım sırasında tüketiciler fonksiyonel, fiziksel, finansal, sosyal, psikolojik risk ve zaman riski olarak altı farklı risk ile karşılaşabilmekte ve bu risklerin ne kadarını üstlenmeyi göze alıyorlarsa ona göre satın alım yapmaktadırlar.

Yapılan bu çalışmada verilen bu bilgiler ve yapılan kapsamlı literatür taraması eşliğinde tüketicilerin davranışları üzerinde önemli etkisi olan ergenlik ayrılma ve bireyselleşmesinin algılanan risk üzerine etkisini incelemek amaçlanmıştır. Öncelikli olarak "Ergenlik Dönemi 
Bireyselleşme ve Ayrılma" ve "Risk Algısı" ölçeklerine ilişkin geçerlilik ve güvenilirlik analizleri yapılmıştır. Sonrasında ise, çalışmanın amacı doğrultusunda elde edilen araştırma bulgularına göre, ayrılık kaygısının ve reddedilme beklentisinin risk algısı üzerinde önemli etkileri olduğu ancak, kısıtlanma kaygısının ise anlamlı etkileri olmadığı görülmüştür. Araştırma bulguları, tüketicilerin risk algıları konusunda yol gösterici olabileceği gibi başka çalışmalar için de faydalı olabilecektir. İzmir ilinde yapılan araştırma küçük bir örneklemden oluşması nedeniyle daha büyük örneklem ile tekrarlanması önerilmektedir.

\section{KAYNAKÇA}

Aslan, S. (2008). Bağlanma ve Uyum Arasındaki İlişkide Ayrışma Bireyselleşmenin Aracılığı. Gazi Üniversitesi Eğitim Bilimleri Enstitüsü Rehberlik ve Psikolojik Danışmanlık Bilim Dalı Yayınlanmaaış Doktora Tezi. Ankara.

Aslan, S. \& Güven, M. (2009). Ergen Ayrışma Bireyselleşme Ölçeğinin Uyarlanması: Geçerlilik ve Güvenirlik Çalışmaları. Çocuk ve Gençlik Ruh Sağlığı Dergisi, 16(3), s. $123-128$.

Atak, H. (2011). Kimlik Gelişimi ve Kimlik Biçimlenmesi: Kuramsal Bir Değerlendirme. Psikiyatride Güncel Yaklaşımlar, 3(1), s. 163-213.

Athearn, J. (1971). What is Risk? The Journal of Risk and Insurance, 38(4), s. 639-645.

Bakan, İ. \& Kefe, İ. (2012). Kurumsal Açıdan Algı ve Algı Yönetimi. Kahramanmaraş Sütçü İmam Üniversitesi İktisadi ve İdari Bilimler Fakültesi Dergisi, 2(1), s. 19 - 34.

Bauer, R. (1974). Consumer Behavior As Risk Taking. R. Karp (Dü.) içinde, Issues in Marketing (Robert S. Hannock (1960) editörlüğünde yayınlanan Proceedings of American Association isimli kitaptan alınarak yeniden yayınlanmıştır. b., s. 47 - 52). New York: MSS Information Corporation.

Brereton, A. (tarih yok). Adolescence and Autism Spectrum. 10 25, 2017 tarihinde Department of Education and Early Childhood Development: https://pdfs.semanticscholar.org/ede6/a3882a8c0b966f2706d4ef3128087d86d6c7.pdf adresinden alınd 1

Business Insider. (2015, 04 15). How teens are spending money, what they like, and where they shop. 12 4, 2017 tarihinde Business Insider: http://www.businessinsider.com/how-teensare-spending-money-2015-4 adresinden alınd

Cheng, F.-F., Liu, T.-Y. and Wu, C.-S. (2013). Perceived Risks and Risk Reduction Strategies in Online Group-Buying. Diversity, Technology, and Innovation for Operational Competitiveness: Proceedings of the 2013 International Conference on Technology Innovation and Industrial Management, s. 1 - 18.

Dal, V.\& Eroğlu, A. (2015). Farklı Kişilik Özelliklerine Sahip Bireylerin Risk Algılarının Tüketici Davranışı Açısından İncelenmesi: Üniversite Öğrencileri Üzerine Bir Araştırma. Süleyman Demirel Üniversitesi İktisadi ve İdari Bilimler Fakültesi Dergisi, 20(2), s. 361 -385 .

Demir, M. (2011). Risk Algısının Marka Sadakatine Etkisi: Cep Telefonları Kategorisinde Bir Uygulama. Ege Akademik Bakış, 11(2), s. 267 - 276. 
Efron, R. (1969). What is Perception? R. Cohen ve M. Wartofsky (Dü) içinde, Proceedings of the Boston Colloquium for the Philosophy of Science 1966/1968 (s. 137 - 173). Dordrecht, Hollanda: D. Reidel Publishing Company.

Field, A. (2000). Discovering Statistics using SPSS for Windows. London, Thousand Oaks, Sage Publications, New Delhi.

Gül, S. \& Güneş, İ. (2009). Ergenlik Dönemi Sorunları ve Şiddet. Sosyal Bilimler Dergisi, 11(1), s. 79 - 101.

Haran, S. (2004). Ergenlerde Gelişimsel Kriz Üzerine Bir Klinik Örnek. Kriz Dergisi, 12(1), s. $47-53$.

Jacoby, J. \& Kaplan, L. (1972). The Components of Perceived Risk. roceedings of the Third Annual Conference of the Association for Consumer Research, s. 382-393.

Jessor, R. (1999). Risk Behavior in Adolescence: A Psychosocial Framework for Understanding and Action. R. Lernerve C. Ohannesian (Dü) içinde, Risks and Problem Behaviors in Adolescence (s. 2 - 19). New York: Garland Publishing, Inc.

Kaplan, S. \& Garrick, J. (1981). On The Quantitative Definition of Risk. Risk Analysis, 1(1), s. $11-27$.

Koç, M. (2004). Gelişim Psikolojisi Açısından Ergenlik Dönemi ve Genel Özellikleri. Hacettepe Üniversitesi Sosyal Bilimler Enstitüsü Dergisi, 2(17), s. 231-256 .

Levine, J., Green, C. and Millon, T. (1986). The Seperation Individuation Test of Adolescence. Journal of Personality Assesment, 50(1), s. 123 - 137.

Levine, J. \& Saintonge, S. (1993). Psychometric Properties of the Separation-Individuation Test of Adolescence within a Clinical Population. Journal of Clinical Psychology, 49(4), s. $492-507$.

Lim, N. (2002). lassification of Consumers' Perceived Risk: Sources versus Consequences. Proceedings of the Sixth Pacific Conference on Information Systems, (s. 540 - 554). Tokyo.

Mahler, M., Pine, F. and Bergman, A. (1975). The Psychological Birth of the Human Infant: Symbiosis and Individuation. London: Hutchinson \& Co Ltd.

Mattanah, J., Hancock, G. and Brand, B. (2004). Parental Attachment, SeparationIndividuation, and College Student Adjustment: A Structural Equation Analysis of Mediational Effects. Journal of Counseling Psychology, 51(2), s. 213 - 225.

Mitchell, V.-W. (1999). Consumer Perceived Risk: Conceptualisation and Models. European Journal of Marketing, 33(1/2), s. 163 - 195.

Özbilgin, İ. (2012). Risk ve Risk Çeşitleri. Bilişsim Dergisi(145), s. 86 - 93.

Özdemir, Y. \& Çok, F. (2011). Ergenlikte Özerklik Gelişimi. Türk Psikolojik Danışma ve Rehberlik Dergisi, 36(4), s. 152-164.

Roselius, T. (1971). Consumer Rankings of Risk Reduction Methods. Journal of Marketing, 35(1), s. 56 - 61.

Sayıl, M., Güre (Yılmaz), A. and Uçanok, Z. (2002). Ergenliğe Geçişte Bilgilendirmenin Ergenin Bilgi Düzeyi ve Benlik Algısına Etkisi. Türk Psikoloji Dergisi, 17(50), s. 47 58. 
Sipahi, B., Yurtkoru, E. S. and Çinko, M. (2011). Sosyal Bilimlerde SPSS'le Veri Analizi. İstanbul: Beta Basım Yayım.

Skjong, R. (2005, 02 25). Etymology of Risk: Classical Greek origin - Nautical Expression Metaphor for. 20 09, 2017 tarihinde http://research.dnv.com/skj/Papers/ETYMOLOGYOF-RISK.pdf" adresinden alınd 1

Statistic Brain. (2017, 10 27). Teenage Consumer Spending Statistics. 12 4, 2017 tarihinde Statistic Brain: https:/www.statisticbrain.com/teenage-consumer-spending-statistics/ adresinden alındı

Stone, R. \& Mason, J. (1995). Attitude and Risk: Exploring the Relationship. Psychology \& Marketing, 12(2), s. 135 - 153.

Taşkın, E., Gürlek Yüksel, E. and Özmen, E. (2009). Üniversite Birinci Sınıf Öğrencilerinde Ayrılma Bireyleşme Özellikleri ve Depresyon İlişkisi. Anatolian Journal of Psychiatry, 10, s. 174-180.

Taylor, J. (1974). The Role of Risk in Consumer Behavior. Journal of Marketing, 38(2):54 60.

Tek, Ö. \& Demirci Orel, F. (2008). Perakende Pazarlama Yönetimi. İzmir: Bileşik Matbaacılık.

Türkiye İstatistik Kurumu. (2016, 12 31). İl, yaş grubu ve cinsiyete göre nüfus, 2007-2016. 12 4, 2017 tarihinde Türkiye İstatistik Kurumu: https://www.google.com.tr/url?sa=t\&rct= $\mathrm{j} \& \mathrm{q}=\& \mathrm{esrc}=\mathrm{s} \&$ source $=$ web\&cd $=1 \& \mathrm{cad}=$ rja\&uact $=8 \& v e d=0$ ahUKEwi_j7LJ-u7XAhU K1RQKHWWqDYEQFggoMAA\&url=http\%3A\%2F\%2Fwww.tuik.gov.tr\%2FPreIstati stikTablo.do\%3Fistab_id\%3D945\&usg=AOvVaw1pbb1ieR2KWGvqKzXCkRYb adresinden alındı

Yüncü, Z., Gürçay, E., Topçu Kabasakal, Z., Özbaran, B., Tamar, M. and Aydın, C. (2009). Madde Kullanım Bozukluğu Olan Ergenlerde Ayrılma Bireyselleşme Süreci. New/Yeni Symposium Journal, 47(4), s. 225 - 234. 


\section{EXTENDED ABSTRACT}

\section{THE EFFECT OF INDIVIDUATION AND SEPARATION OF ADOLESCENCE ON CONSUMER'S PERCEPTION OF RISK}

Nowadays it has become almost impossible for individuals to spend a day without shopping. Consumers in the shopping process perceive various risks at many different points. One of the important periods in embodiment of consumer's risk perceptions is the adolescence. Adolescence, which is defined as a period when individuals cannot fully taken into account as adults, ends with individuals' intense physical, mental and social - emotional changes and finally self - recognition. While consumers' risk perceptions differ for different product categories, in this period the spiritual conflicts in which the individuals live in their own, can also significantly shape risk perceptions. For this reason, adolescence is a period that should be examined in terms of consumer behaviour. However, many studies that are aiming to contribute to the literature on consumer behaviour do not investigate the period of adolescence in which personality formation is largely completed. This study aims to make contribution to the literature about consumer risk perception and to investigate effects of individualization separation that consumers are experiencing at adolescence at which they change emotionally, physically, psychologically etc.

The sample of the study consisted of 370 students including 193 female and 177 male students, aged between 17 and 31 years, who were educated at Dokuz Eylul University Faculty of Economics and Administrative Sciences during the spring semester of 2016 - 2017 academic year. The main reason of selecting university students as the sample in the study is because at adolescence, which is the second Individuation separation process, the terms passing at university is the period which the development is prominent, individuals are far from their parents and make independent decisions. Survey technique was used as data collection method in order to obtain primary data. The Separation Individuation Test of Adolescence (SITA) which is developed by Levine et al. (1986) was used to measure individuation - separation behaviour during adolescence. The "Perceived Risk" scale, which Stone and Mason developed in 1995 was used to measure the six risk groups (functional risk, financial risk, social risk, physical risk, psychological risk and time risk) identified by literature review.

Within the scope of the research, primarily, validity and reliability analyses of "The Separation Individuation Test of Adolescence" and "Perceived Risk" scales were conducted. Separation individuation of adolescence includes factors as separation anxiety, engulfment anxiety and rejection expectancy. In addition, functional, financial, social, time, psychological and physical risks are considered as dimensions of perception of risk. Afterwards, the effects of individuation and separation on adolescents' risk perceptions were examined. Separation anxiety, which is the sub-dimension of the Separation Individuation Test of Adolescence; effects perceived risk subscales functional risk, physical risk and time risk positively. Besides, as rejection expectancy affects social risk and time risk positively; its effect on functional risk and physical risk are negative. In this context, it is thought that it is necessary to express individuation and separation behaviours of adolescence as an important issue that has an effect on consumers' perception of risk. It is foreseen that this study will be a mentor in terms of both contributing to the current literature and being a guide in other work to be done. 